Pesq. Vet. Bras. 31(3):247-254, março 2011

\title{
The use of enzyme-linked immunosorbent assay and immunoblotting for the detection of Campylobacter fetus immunoglobulins in the cervico-vaginal mucus of female cattle ${ }^{1}$
}

\author{
Aiesca O. Pellegrin $2,3^{\star}$, Karina L. Miranda ${ }^{3}$, Josely F. Figueiredo ${ }^{3}$, \\ Edel F. Barbosa ${ }^{4}$ and Andrey P. Lage ${ }^{3}$
}

\begin{abstract}
Pellegrin A.O., Miranda K.L., Figueiredo J.F., Barbosa E.F. \& Lage A.P. 2011. The use of enzyme-linked immunosorbent assay and immunoblotting for the detection of Campylobacter fetus immunoglobulins in the cervico-vaginal mucus of female cattle. Pesquisa Veterinária Brasileira 31(3):247-254. Embrapa Pantanal, Rua 21 de Setembro 1880, Corumbá, MS 79320-900, Brazil. E-mail: aiesca@cpap.embrapa.br

An indirect enzyme-linked immunosorbent assay was developed to detect antigenspecific secretory IgA antibodies to Campylobacter fetus subsp. venerealis in bovine vaginal mucus with a protein extract of the Campylobacter fetus subsp. venerealis by the acid glycine extraction method. Mean optical density measurement $(\lambda=450 \mathrm{~nm})$ was $0.143 \pm 0.9$. The most immunoreactive protein bands of the Campylobacter fetus subsp. venerealis or Campylobacter fetus subsp. fetus recognized by IgA in immunoblotting, using bovine vaginal mucus samples, migrate at $42.6 \mathrm{kDa}$. The protein that migrates at 93 $\mathrm{kDa}$ was recognized exclusively for $C$. fetus subsp. venerealis. A positive vaginal mucus sample of a cow from negative herd recognized antigens of $C$. jejuni subsp. jejuni e $C$. fetus subsp. fetus.
\end{abstract}

INDEX TERMS: Campylobacter fetus, Campylobacteriosis, ELISA, immunoglobulin A.

RESUMO.- [Uso do ensaio imunoenzimático e imunoblotting para detecção de imunoglobulinas contra Campylobacter fetus em muco cérvico-vaginal de fêmeas bovinas.] Foi padronizado um ensaio imunoenzimático do tipo indireto para detecção de imunoglobulina A (ELISA $\lg A$ ) anti- Campylobacter fetus subp. venerealis em muco cérvico- vaginal bovino utilizando um extrato protéico de Campylobacter fetus subsp. venerealis produzido pelo método de extração ácida pelo tampão de glicina $(0,2 \mathrm{M}$; $\mathrm{pH} 2,2)$. A média dos valores de densidade ótica $\left(\mathrm{DO}_{450}\right)$ foi de $0,143 \pm 0,09$. As bandas protéicas dos antígenos de

\footnotetext{
${ }^{1}$ Received on December 16, 2009.

Accepted for publication on September 6, 2010.

2 Embrapa Pantanal, Rua 21 de Setembro 1880, Corumbá, MS 79320900, Brazil. *Corresponding author: aiesca@cpap.embrapa.br

${ }^{3}$ Departamento de Medicina Veterinária Preventiva, Escola de Veterinária, Universidade Federal de Minas Gerais (UFMG), Av. Antônio Carlos 6627, Cx. Postal 567, Belo Horizonte, MG 30123-970, Brazil.

4 Instituto de Ciências Biológicas, UFMG, Av. Antônio Carlos 6627, Cx. Postal 567, Belo Horizonte, MG 30123-970.
}

Campylobacter fetus subsp. venerealis e de Campylobacter fetus subsp. fetus melhor reconhecidas pela IgA do muco cérvico- vaginal migraram em 42,6 kDa mas a proteina evidenciada em $93 \mathrm{kDa}$ foi reconhecida exclusivamente pelo Campylobacter fetus subsp. venerealis. Os anticorpos presentes na amostra de muco vaginal testada no "immunoblotting" que apresentou resultado positivo no ELISA IgA, reconheceu antígenos de $C$. jejuni subsp. jejuni e $C$. fetus subsp. fetus.

TERMOS DE INDEXAÇÃO: Campylobacter fetus, Campilobacteriose, ELISA, imunoglobulina $A$.

\section{INTRODUCTION}

Bovine Genital Campylobacteriosis (BGC) is a specific reproductive disease, which can cause embryonic death, resulting in irregular cycles, and, less often, abortions (Dekeyser 1986). Immunity against Bovine Genital Campylobacteriosis is mainly local, with the production of IgA class immunoglobulins in the vaginal and uterine mucosa, as investigated in naturally or experimentally infected bovine females (Corbeil et al. 1974b). 
The kinetics of immunity against Campylobacter fetus in the vaginal mucosa shows that IgM are the first immunoglobulins to appear in experimentally infected heifers, followed by IgA, and eventually by IgG1 (Corbeil et al. 1974a,b, Van Aert et al. 1977). In heifers infected by the vaginal route, the emergence of $\operatorname{lgM}$ and $\lg A$ is almost simultaneous, before IgG1, which appears around the 8th week post-infection. This emphasizes the importance of the immunity provided by IgA for the resistance against natural infection by $C$. fetus, as IgM, IgG1 and IgG2 develop in systemically vaccinated females (Corbeil et al. 1974a).

High-molecular-weight proteins of the outer membrane (OMPs), named S-layer (SAP) are considered important virulence factors for $C$. fetus, responsible for resistance to phagocytosis and avoiding bactericidal activity of serum immunoglobulins (Blaser 1983). In bovine isolates of Campylobacter fetus from bulls, cows and aborted fetus of brazilian herds, ten different patterns of SAP expression were demonstrated by identification of proteins with molecular mass of $97,100,127$, and $149 \mathrm{kDa}$, obtained by an acid (glicin) method of extraction (Vargas et al. 2002). Experiments using mouse and bovine models sugest that $\mathrm{S}$-layer proteins is a dominant virulence factor enabling persistence in the genital tract (Garcia et al. 1995) by inversion events resulting in expression of antigenically variant S-layers (Thompson 2002, Vargas et al. 2002) .S-layer proteins conferes resistance to systemic defenses (Pei \& Blaser 1990, Blaser \& Pei 1993) preventing the binding of complement factor C3b to the $C$. fetus surface (Blaser 1988).

Among the serological techniques used for the detection of the immune response, the enzyme-linked immunosorbent assay is widely accepted as very sensitive, and therefore, it is very convenient to be used in laboratories. However, its sensitivity and specificity essentially depend on the preparation of the antigen used in the test (Hirschl \& Rotter 1990) and on the established cutoff (Smith 1994).

Several authors have used in the solid phase of the enzyme-linked immunosorbent assay acid extractable antigens (Blaser et al. 1983, Dunn et al. 1987), sonicated (Hewson 1985, Dunn et al. 1987) or by distilled water extraction (Garcia et al. 1995). These antigens can be classified as partially purified antigens, resulting in high sensitive and specific tests, as compared to non-purified antigens, which are less specific, or to highly purified antigens, which are less sensitive (Hirschl \& Rotter 1990).

The use of an enzyme-linked immunosorbent assay for the detection of $C$. fetus subsp. venerealis-female carriers was previously described, and this test is considered more sensitive as compared to the mucus agglutination test for the detection of anti-Campylobacter fetus class $\mathrm{G}$ immunoglobulins in the early stages of infection (Hewson 1985). However, the latter has good specificity for the detection of specific immunoglobulins $A$ in bovine females that aborted due to natural infection by $C$. fetus subsp. venerealis (Hum et al. 1991).

This study aimed at standardizing an enzyme-linked immunosorbent assay by comparing an antigen obtained by acid extraction with glycine buffer to a sonicated antigen employed in the solid phase for the detection of anti-C. fetus immunoglobulins $A$, and evaluating the humoral immune response in the cervico-vaginal mucus of virgin heifers.

\section{MATERIALS AND METHODS}

Animals. The negative controls were provided by samples of the cervico-vaginal mucus collected from 44 virgin heifers between 12 and 24 months of age. These heifers were selected from a Bovine Genital Campylobacteriosis-free herd, exclusively under artificial insemination (Al). The positive controls were provided by samples of the cervico-vaginal mucus collected from cows of herds with positive diagnosis of Campylobacteriosis that had aborted or had reproductive failure.

Samples. For cervico-vaginal mucus vaginal collection, a previously weighed tampon (Sempre Livre, Jonhson \& Johnson, São Paulo) was introduced in the vagina of the heifers with the aid of an applicator coupled to a metal tube. The tampon remained on the wall of the vaginal cavity for at least 30min for saturation (Fernandes \& Gomes 1992). The tampon was then removed, placed in a sterile container, and transported in ice to the laboratory, where it was weighted. Sample weight was recorded for later calculation of the amount of diluent (PBS + $0.05 \%$ Tween $20, \mathrm{pH} 7.4$ ) to be used in order to obtain an initial dilution of $1 / 10$. After diluent addition, the tampon was pressed with a sterile glass bar for the removal of the cervico-vaginal mucus, which was then divided in aliquots and stored under refrigeration until use.

Reference samples and culture conditions. Campylobacter fetus subsp. venerealis NCTC 10354 (serotype A), C. fetus subsp. fetus ATCC 27354 (serotype B) and C. jejuni subsp. jejuni NCTC 11351 samples were used to produce the antigens. Samples were cultivated in $\mathrm{BHI}$ agar (Brain Heart Infusion, Difco, USA) with $10 \%$ equine blood for 48 hours at $37^{\circ} \mathrm{C}$, in microaerophilic atmosphere containing $85 \% \mathrm{~N}_{2}, 10 \% \mathrm{CO}_{2}$ and $5 \%$ $\mathrm{O}_{2}$.

Animals. The negative controls were provided by samples of the cervico-vaginal mucus collected from 44 virgin heifers between 12 and 24 months of age. These heifers were selected from a Bovine Genital Campylobacteriosis-free herd, exclusively under artificial insemination (AI). The positive controls were provided by samples of the cervico-vaginal mucus collected from cows of herds with positive diagnosis of Campylobacteriosis that had aborted or had reproductive failure.

Acid- extractable antigen. The procedure proposed by McCoy et al. (1975) was used for the production of the antigen by acid extraction. After cultivation colonies were removed from the plates with PBS ( $\mathrm{pH} \mathrm{7.4),} \mathrm{and} \mathrm{rinsed} \mathrm{three} \mathrm{consecutive}$ times with this buffer in a centrifuge at $10,000 \times \mathrm{g}$ for 20 minutes at $4^{\circ} \mathrm{C}$. After the third rinsing, the sediment was suspended in glycine- $\mathrm{HCl}$ buffer (0.2 M, pH 2.2), at a proportion of $100 \mathrm{ml}$ of buffer per $4 \mathrm{mg}$ of wet bacterial mass, and submitted to agitation for 30 minutes. The suspension was again centrifuged at 13,000 $x \mathrm{~g}$ for 20min, and the supernatant was dialized against deionized and distilled water for 48 hours, and later concentrated approximately 10 times in sucrose gradient. Protein was estimated by the method of Lowry (Sambrook 2001) using bovine albumin (Sigma, USA) as standard. Subsequently, the acid extraction in glycine buffer antigen was divided in aliquots and stored at $-20^{\circ} \mathrm{C}$.

Sonicated antigen. The sonicated antigen was prepared according to the protocol described by Hewson (1985), 
reducing sample incubation time from 72 to 48 hours and using a standard sample of $C$. fetus subsp. venerealis (NCTC10354). The culture was collected from the medium with a phosphate buffer saline solution (PBS, $\mathrm{pH} 7.4$ ), rinsed three times by centrifugation at $13,000 \times \mathrm{g}$ per $20 \mathrm{~min}$ and the sediment collected . Finally, the sediment was re-suspended in $10 \mathrm{ml}$ of a buffer containing $0.5 \mathrm{M}$ potassium chloride and $0.1 \%$ (vol/vol) cystein hydrochloride, sonicated for $630-\mathrm{sec}$ cycles of $70-80 \mathrm{~Hz}$ power, with 1-min resting intervals, subsequently concentrated and divided in aliquots.

Enzyme linked immunoassay (ELISA). The acid extractable antigen was diluted in carbonate-bicarbonate buffer, $\mathrm{pH}$ 9.6 (Voller, 1979) and adsorbed to plated (Maxisorp, Nunc) for $18 \mathrm{~h}$ at $4^{\circ} \mathrm{C}$, in wet chamber. After rinsing, the plate was treated with PBS Tween $20(0.05 \%)$ (PBST) with addition of $5 \%$ nonfat dry milk for $30 \mathrm{~min}$ at $37^{\circ} \mathrm{C}$ for unspecific site blocking. Incubation times and temperatures were: for the sample (cervico-vaginal mucus), $1 \mathrm{~h}$ at $37^{\circ} \mathrm{C}$ in humid chamber; for the conjugate, $1 \mathrm{~h}$ at $37^{\circ} \mathrm{C}$ in humid chamber; and for the substrate, $15 \mathrm{~min}$ at environmental temperature in dark room. PBST with addition of $1 \%$ nonfat dry milk was used in the rinsing stages. Checkerboard titration were used to optimisation and standardisation of reagents. Two antigen concentrations (500 and 250ng/100ul) and two dilutions of the peroxidase conjugated bovine anti-lgA (Bethyl) in $1 / 10,000$ and $1 / 20,000$ dilutions were tested with a $1 / 50$ dilution of the cervico-vaginal mucus.

The chromogenic substrate used were 3, 3'5, 5'-Tetramethylbenzidine (TMB, Sigma, USA) and 1M H2SO4 as stop solution. Readings were made at a spectrophotometer with $450 \mathrm{~nm}$ filter. The optimal antigen and conjugated concentrations and sample dilution per well, determined by checkerboard titration against positive and negative control serum, were found to be of $250 \mathrm{ng}$ for the antigen, $1 / 10,000$ for the anti-IgA conjugated, $1 / 50$ for the mucus, respectively,

Polyacrylamide gel electrophoresis (SDS-PAGE). Ten mg of the antigen produced by acid extraction of each of the Campylobacter spp. (C. fetus subsp. fetus, $C$. fetus subsp. venerealis, C. jejuni subsp. jejuni) were used in each well, and the protein components were separated by electrophoresis according to the system described by Laemmli (1970). Low Range (BioRad, USA) or Broad Range (BioRad, USA) molecular weight standards were used and gels were stained by the method of Coomassie Blue (Sambrook et al. 1989).

After electrophoresis, proteins were transferred from the gel to a nitrocellulose membrane (Sigma, USA) using Tris glycine buffer containing 20\% methanol in Transblot system (BioRad, USA) for $1 \mathrm{~h} 30 \mathrm{~min}$ at $100 \mathrm{~V}$ (Bjerrum \& Heegaard 1988). After transference, inespecific sites were blocked with Tris- $\mathrm{NaCl}$ Tween 20 (0.05\%) (TBS) buffer containg 5\% nonfat dry milk for $18 \mathrm{~h}$ at $4^{\circ} \mathrm{C}$. Several dilutions of the cervico-vaginal mucus were previously tested $(1 / 10,1 / 20,1 / 25,1 / 50)$, and the best dilution selected for immunoblotting was $1 / 50$. For the recognition of the antigen protein, a pool of cervico-vaginal mucus of ten positive animals in the IgA ELISA test, diluted 1/10 in TBS was used as positive control, and a pool of cervicovaginal mucus of ten negative animals in the IgA ELISA test, sampled among the virgin heifers, was used as negative control. The bovine anti-IgA Peroxidase (Bethyl, USA) conjugate was used in a 1/1000 dilution, and the substrate was 4-chloronaphtol (Sigma, USA). The reaction times used were $1 \mathrm{~h} 30 \mathrm{~min}$ for the antibody, $1 \mathrm{~h}$ for the conjugate, and $10 \mathrm{~min}$ for the substrate, and three 10-min rinsings of the membrane were performed with TBS buffer between each reaction phase.
Statistical analysis. The different antigen preparations were compared by analysis of variance using a randomized block experimental design $(P \leq 0.05)$, whereas the acid preparations employing different antigens were compared by analysis of variance for a completely at ramdom experimental design $(P \leq 0.05)$ (Sampaio 1998).

\section{RESULTS}

The optimal Elisa reagents concentrations and sample dilution per well, determined by checkerboard titration were found to be of 250ng for the antigen, $1 / 10,000$ for the anti$\lg A$ conjugated, 1/50 for the mucus, respectively.

Cutoff was calculated by the mean of the results obtained in cervico-vaginal mucus samples of 44 virgin heifers $(0.143$ $\left.\mathrm{OD}_{450}\right)$ plus two standard deviations $\left(0.09 \mathrm{OD}_{450}\right)$. Therefore, samples presenting readings at $450 \mathrm{~nm}$ equal or higher than 0.323 were considered as positive.

For the comparison between sonicated and acid-extraction antigens, 35 samples of the cervico-vaginal mucus were collected at random and tested by IgA ELISA, using antigen preparations produced by acid extraction and sonicated extract. The results did not show significant differences ( $P>0.05$ ) among the absorbance values of each antigen in the positive and negative herds, with a difference between means of 0.3806 and 0.3391 , respectively, and a calculated least significant difference (LSD) of $0.150 \mathrm{OD}_{450}$, which was lower than the difference between the means of the two antigens $\left(0.0415 \mathrm{OD}_{450}\right)$. The antigen produced by glycine acid extraction was used to evaluate the humoral response of virgin heifers as it was easier to produce as compared to the sonicated antigen, and also because the results obtained with both antigens were similar.

In the solid phase of the comparison trial, antigens obtained by acid extraction of the species of Campylobacter fetus subsp. fetus, $C$. fetus subsp. venerealis, and $C$. jejuni subsp. jejuni, were used in different polystyrene "Maxisorb" plates with 96 wells (Nunc, USA). General means of obtained in optical density measurements were 0.253, 0.226, and 0.209, respectively, for $C$. fetus subsp. venerealis, $C$. fetus subsp. fetus, and $C$. jejuni subsp. jejuni, with a calculated least significant difference of 0.027 . There was a significant difference $(P<0.05)$ in the detection of immunoglobulins $A$ when $C$. fetus subsp. venerealis was used as compared to the other samples, but this difference was not detected when $C$. fetus subsp. fetus and $C$. jejuni subsp. jejuni $(\mathrm{P}>0,05)$ were compared.

The profile of the sonicated antigen produced with the NCTC 10354 sample showed the presence of several protein bands with different molecular weights, which varied between 131.7 and $24.8 \mathrm{kDa}$. The most evident proteins migrated at 90.8, 57.5, 49.0, 45.5, 40.0, and $36.4 \mathrm{kDa}$, using Broad Range (BioRad, USA) as molecular weight standard (eletroforetic profile not showed).

In the antigen of $C$. fetus subsp. venerealis NCTC 10354 obtained by acid extraction with glycine buffer ( $\mathrm{pH} 2.2)$, the most evident bands migrated in 93, 56.6, 42.8, 40.1, 32.8, 28.9, and $25.7 \mathrm{kDa}$ regions (Fig. 1). In the antigen of $C$. 


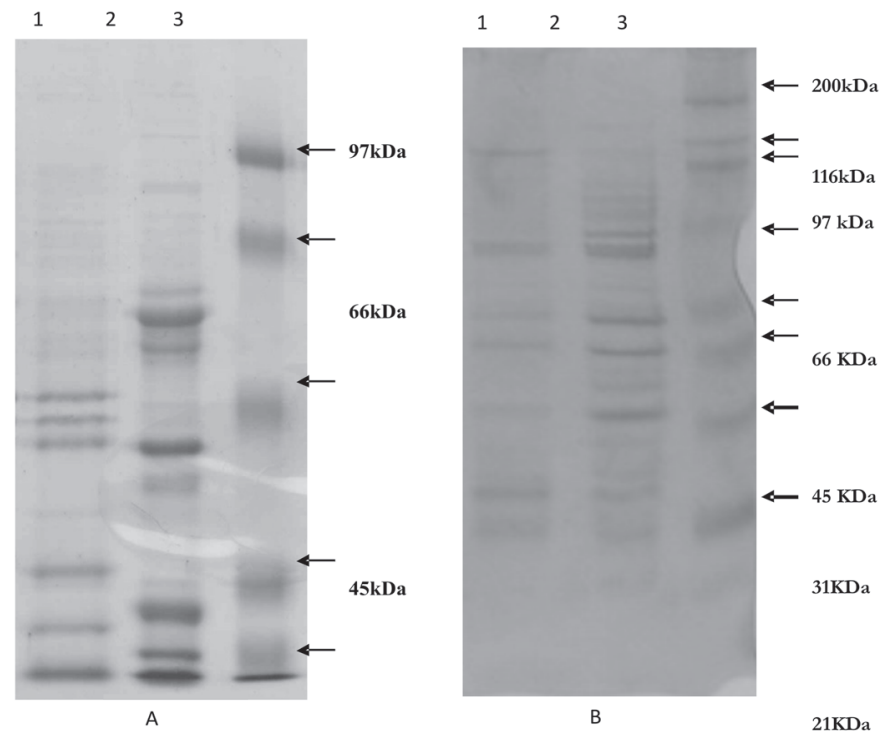

Fig.1. Gel with $12 \%$ acrylamide stained with Coomassie blue using $10 \mathrm{~g}$ of an acid (glicin) extratable antigen per well. (A.1) Campylobacter fetus subsp. venerealis; (A.2) C. fetus subsp. fetus; (A.3) Broad Range Standard (BioRad); (B.1) C. fetus subsp. venerealis; (B.2) C. fetus subsp. fetus; ( B.3) LowRange Standard (BioRad, Sigma).

fetus subsp. fetus ATCC 27374, 10 protein bands between 56.7 and $25.8 \mathrm{kDa}$ were detected. The most evident bands appeared between 45 and $31(42.8,40.1$, and $37.8 \mathrm{kDa})$ and immediately below $(28.5$ and $25.8 \mathrm{kDa})$. When these two antigens were analyzed together, it is possible to observe several proteins with similar molecular weights, migrating in 56.7, 42.8, 40.1, 25.8, and $25.7 \mathrm{kDa}$, among those that were visually different.

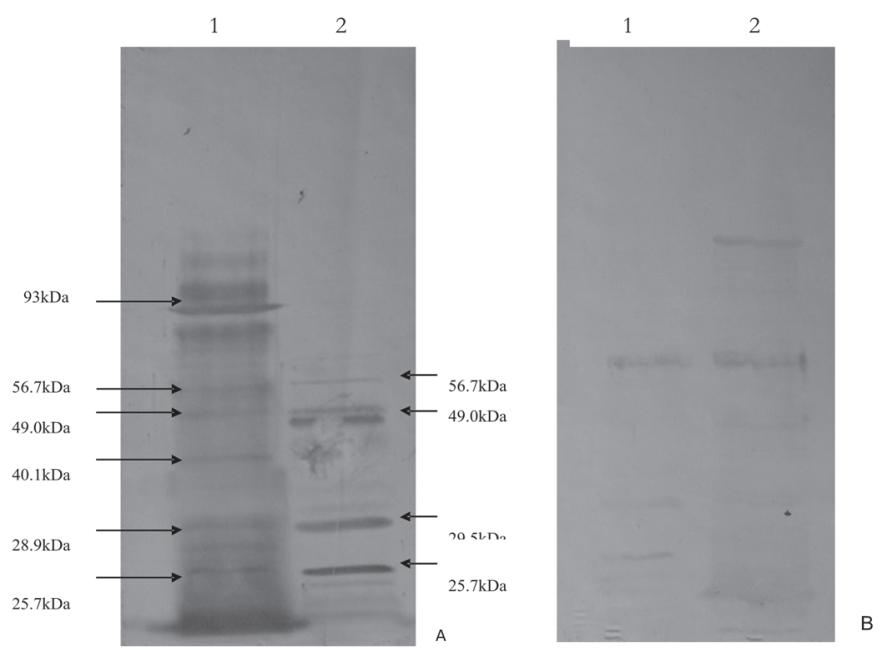

Fig.2. "Immunoblott" de proteínas de antígeno obtido por extração ácida de Campylobatcer fetus venerealis (1) e C.fetus fetus (2), utilizando $10 \mathrm{mg}$ de antígeno por canaleta e muco vaginal positivo ao Elisa IgA diluído 1:10 (A) e mistura de amostras de muco vaginal positivo ao Elisa IgA diluído 1:20 (B). Os imunoblotts foram visualizados utilizando um soro anti-IgA bovina (Bethyl) conjugado com peroxidase em diluição 1:1000 e revelação com 4-cloronaftol.
For the antigen $C$. jejuni subsp. jejuni NCTC1135, 11 different bands, from $84.5 \mathrm{kDa}$ to $24.8 \mathrm{kDa}$ were observed. The larger bands migrated in $84.5,58.9,53.6,49.5,37.4$, $34.2,26.4$, and $24.8 \mathrm{kDa}$, although the analysis identified the presence of bands in in $41.7,32.4$ and $27.8 \mathrm{kDa}$ (eletroforetic profile not showed).

Immunoglobulins A recognized in the cervico-vaginal mucus seven proteins of the antigen of $C$. fetus subsp. venerealis, which migrated in 93, 56.7, 49.8, 40.1, 36.0, and $28.9 \mathrm{kDa}$. An intermediate band was observed between 28.9 and $25.7 \mathrm{kDa}$, when the cervico-vaginal mucus was diluted at 1:10 (3-A), whereas only two main bands of 93 and $43 \mathrm{kDa}$ (Fig.2) were present in a higher dilution (1:20). When the $C$. fetus subsp. fetus was tested against the cervico-vaginal mucus diluted at 1:20, six proteins were immunoreactive (56.7, 49.6, 42.6, 29.5 and $25.8 \mathrm{kDa}$ ), whereas when the sample was diluted at $1: 10$, only proteins with molecular weights of $42.6,29.5$, and $25.8 \mathrm{kDa}$ were visualized in the nitro-cellulose membrane (Fig.2). The bands recognized in both antigens weighed $56.7 \mathrm{kDa}$, approximately $49 \mathrm{kDa}$ (49.8, in C. fetus subsp. venerealis and 49.6 in C. fetus subsp. fetus), and $29 \mathrm{kDa}$ (28.9 in $C$. fetus subsp. venerealis) and 29.5 in C. fetus subsp. venerealis). Several proteins weighting less than $25 \mathrm{kDa}$ were also recognized for $C$. fetus subsp. venerealis (Fig. 2).

Cervico-vaginal mucus samples, positive in the IgA ELISA, collected from animals of a dairy herd with no history of $B G C$ that used artificial insemination, were tested against acid-prepared antigens produced with samples of $C$. fetus subsp. venerealis, $C$. fetus subsp. fetus, and $C$. jejuni subsp. jejuni, by immunoblotting in three dilutions: $1: 25$, $1: 50$, and $1: 100$. These samples presented similar patterns for the recognition of IgA antibodies both for $C$. fetus subsp. venerealis and for $C$. jejuni subsp. jejuni. In 1:25 dilution, $56.7,42.6,29.5$, and $25.7 \mathrm{kDa}$ bands were observed in all three antigens, and a $42.6 \mathrm{kDa}$ band in $C$. fetus subsp. venerealis and $C$. fetus subsp. fetus, which was probably represented by a $41.7 \mathrm{kDa}$ band in $C$. jejuni subsp. jejuni. When dilution increased to 1:50, 56.7 and $42.6 \mathrm{kDa}$ bands remained visible, but could no longer be observed. The highest immune reactivity occurred in the $42.6 \mathrm{kDa}$ (Fig.2) protein of $C$. fetus subsp. fetus.

\section{DISCUSSION}

The antigen profile, demonstrated by electrophoresis in polyacrylamide gel both for the sonicated antigen and the acid-extraction antigen, demonstrated similarities as to protein migration around $97 \mathrm{kDa}$ or below $(93 \mathrm{kDa})$, and in $63,42.6,29$, and $25 \mathrm{kDa}$. In the immunoblotting test, these proteins were immunoreactive, and were recognized by the IgA present in the tested vaginal mucus, when the acid extract of Campylobacter fetus subsp. venerealis was used. This confirms the similar results $(P>0.05)$ obtained in the enzyme-linked immunosorbent assay, which compared the sonicated and the acid-extracted antigens as to the detection of anti-Campylobacter fetus immunoglobulins A in the cervico-vaginal mucus. Therefore, this suggests that 
the sonicated agent may be an alternative that can be used in the solid phase of enzyme-linked immunosorbent assays aiming at the detection of these immunoglobulins.

A comparison of the sensitivity and the specificity of several antigen preparations (Lewalla-Guruge et al. 1992) for the detection of anti-Helicobacter pylori IgG antibodies concluded that these test properties were equivalent both for sonicated and acid-extracted antigens, which was confirmed by this study.

The cutoff was determined by the mean of the optical density measurements of 44 samples of the cervico-vaginal mucus of virgin heifers, with ages between 12 and 24 months, derived from herds with no history of the disease. The anti-C. fetus subsp. venerealis IgA Elisa standardized in the present study was interpreted using the value of the cutoff plus two standard deviations, in order to increase test specificity, and to decrease the number of false negative results. This procedure were employed because samples from positive animals were not available due to the lack of success in the isolation of $C$. fetus subsp venerealis in suspected herds. The interpretation of the results of a enzyme-linked immunosorbent assay mainly depends on the cutoff established for the test and the aim of the test (Smith 1994). Similar procedures were employed by Hewson (1985) and Hum et al. (1991) for the establishment of test cutoffs. Test cutoff was determined by Hewson (1985) as the mean of $\mathrm{OD}_{450}$ values of 54 females with a positive diagnosis of Bovine Genital Campylobacteriosis by isolation, plus three standard deviations. Hum et al. (1991), on the other hand, expressed test results in ELISA Values (EV), based on $\mathrm{DO}_{450}$ measurements corrected for the $\mathrm{OD}_{450}$ values of positive $\left(\mathrm{OD}_{450}=1.430\right)$ and negative $\left(\mathrm{OD}_{450}=0.180\right)$ controls plus two standard deviations. Their aim was to detect abortions due to $C$. fetus subsp. venerealis. Another cutoff was later established by the same authors, being higher due to the use of three standard deviations, aiming at achieving higher test specificity for the diagnosis of $C$. fetus subsp. venerealis female carriers in herds (Hum et al. 1994).

McFadden et al (2005) performing a screening for campilobacteriosis in 125 beef cow herds in New Zealand established a cutoff for positive result of $33 E V$ (Elisa value), determinated as the sum of the mean EV of the negative controls plus three standard deviations, the same adopted by Hum et al. (1994). The results obtained as previously described (Hewson 1985, Hum et al. 1991, Hum et al. 1994, McFadden et al. 2005) cannot be fully compared to the results obtained in the present study. In the assay standardized by Hewson (1985) and Cobo et al. (2003) a sonicated antigen was used, measuring the IgG-mediated local response, whereas Hum et al. (1991) and McFadden et al. (2005) used a crude antigen, which is considered less specific than the semi-purified antigens (Hirschl \& Rotter 1990), such as the antigen preparation by acid extraction used in this study. The authors considered the specificity of the test unsatisfactory to for detecting infection under field conditions, probably due to cross reaction to
Campylobacter species other than C. fetus subsp. venerealis, from prepucial washings from bulls of three tested herds. In this work, culture of $C$. fetus was not performed, but this possibility cannot be discounted.

The results found in IgA Elisa demonstrated that immunoglobulins $A$, present in the cervico-vaginal mucus of healthy and infected females, recognize antigen proteins of the Campylobacter sp. The virgin heifers used to establish the test cutoff were 12 to 24-months-old and derived from herds under Al service. Although they were not under the risk of a $C$. fetus infection, the mean $\mathrm{OD}_{450}$ measurements obtained by IgA ELISA was 0.143 , with a standard deviation of 0.09 , indicating the occurrence of a substantial amplitude in optical density measurements. Data presented by Hum et al. (1994) also showed a considerable amplitude of $\mathrm{OD}_{450}$ values, with $10 \mathrm{EV}$ with a standard deviation of 15 $\mathrm{EV}$ in the values detected by IgA ELISA.

The role of outer membrane antigens in enzyme-linked immunosorbent assays have been determined by immunoblotting using monoclonal or polyclonal sera for the identification of immunoreactive proteins (Hirschl \& Rotter 1990). In the present study, instead of polyclonal sera, the sample tested by immunoblotting was a cervico-vaginal mucus pool, as one of the objectives of this study was to standardize the test for IgA-mediated local response to $C$. fetus subsp. venerealis. The importance of $\lg A$ in the local immune response to $C$. fetus subsp. venerealis was discussed for naturally infected females, females that aborted, and those that only maintained persistent infection by Wilkie et al. (1972), Corbeil et al. (1975), Winter (1982), Hum et al. (1991, 1994).

Immunoblotting performed with acid-extracted antigens of C. fetus subsp. venerealis NCTC 10354 and $C$. fetus subsp. fetus ATCC 27374 samples revealed the presence of proteins with similar molecular weights for both subspecies. There was a coincidence of protein migration around $49 \mathrm{kDa}$ to $49.8 \mathrm{kDa}$ for $C$. fetus subsp. venerealis, and $49.6 \mathrm{kDa}$ for $C$. fetus subsp. fetus antigen proteins, which are probably similar (Fig.2). This protein that migrated around $49 \mathrm{kDa}$ showed correspondence in all electrophoresis profiles, varying from $49.4 \mathrm{kDa}$ (in $C$. jejunisubsp. jejuni) to $49.8 \mathrm{kDa}$ (in C. fetus subsp. venerealis and $C$. fetus subsp. fetus).

Proteins with molecular weights around $29 \mathrm{kDa}(28.9$ and 29.5) were shown both in C. fetus subsp. venerealis and $C$. fetus subsp. fetus as well as proteins weighing below 25.7 in both antigens.

The study of protein profiles of several $C$. fetus subsp. fetus and $C$. subsp. jejuni antigen preparations revealed a isomeric form of OMP de $43 \mathrm{kDa}$ (or $45 \mathrm{kDa}$ ). In C. jejuni, this monomer can vary between 43 and $45 \mathrm{kDa}$, depending of the studied samples, but it was always present in the samples analyzed by Dunn et al. (1987), representing 70\% of the capsular component of the outer membrane. The observation of the profile of $C$. fetus subsp. fetus obtained in the present study allows us to assume that these proteins are similar. However, this can only be asserted by the use of bi-dimensional polyacrylamide gel electrophoresis.

Immunoglobulins A present in the cervico-vaginal mucus 
detected a large number of proteins of the acid-extracted antigen. Among the protein panel of $C$. fetus subsp. fetus, 28.9 and $25.7 \mathrm{kDa}$ proteins were detected, but not in $C$. fetus subsp. venerealis by immunoblotting. .Studies indicate that proteins migrating between 29 and $31 \mathrm{kDa}$ are superficially exposed and very antigenic, and can be extracted at low $\mathrm{pH}$. These proteins were observed in all $C$. jejuni samples studied by Dunn et al. (1987). Trust \& Logan (1984) previously suggested that these microcapsular components have good specificity, allowing the detection of $C$. jejuni and $C$. coli in human clinical specimens, and also its use for the production of a specific vaccine (McCoy et al. 1975, Logan \& Trust 1986, Dunn et al. 1987).

In this study, two low molecular weight proteins, of about 21 and $31 \mathrm{kDa}$, were strongly immunogenic in the immunoblotting of $C$. fetus subsp. venerealis and $C$. fetus subsp. fetus glycine-extracted antigens and cervico-vaginal mucus of positive females derived from suspected/positive herds. Dunn et al. (1987) suggest that these proteins represent a capsular component of $C$. jejuni, which is actually represented by several proteins (Trust \& Logan 1984), similar to those observed in the protein profile of $C$. jejuni subsp. jejuni.

The false positive results in animals with no clinical signs of the disease and derived from herds with no history of BGC may be attributed to the recognition, in the $\lg A$ ELISA test, of microcapsular proteins weighing about 31 $\mathrm{kDa}$ (28.9 and $25.7 \mathrm{kDa})$. Immunoglobulins A may be present in healthy animals, which had contact with $C$. fetus subsp. fetus, serotype B (Hum et al., 1994). This is clear when we consider that the $C$. fetus subsp. fetus ATCC 27374 sample belongs to serotype B. The genus Campylobacter, particularly the species $C$. fetus, $C$. jejuni, and $C$. coli, has several wall antigens with similar molecular weights (Logan \& Trust 1983, 1986).

A protein migrating at approximately $63 \mathrm{kDa}$, which possibly is the flagellar antigen, was observed in the electrophoresis profile of the three subspecies studied here. However, immunoblotting results indicated a weak recognition by the anti-Campylobacter fetus IgA present in the tested vaginal mucus when the antigen produced with a sample of C. fetus subsp. venerealis was used. This protein was also not recognized by the sample of $C$. fetus subsp. fetus, when the mucus of positive females was used. Although this protein is common to the three subspecies, it is possible that it is an antigen specifically recognized by antibodies produced against $C$. fetus subsp.venerealis in this study. However, Logan \& Trust (1983) asserted that it is recognized by immunoglobulins $G$ in the immunoblotting performed with $C$. jejuni proteins and Zhao et al. (2010) developed and evaluated an highly specific and sensitive indirect ELISA for the detect of IgG antibodies against $C$. fetus in cattle sera using as the test antigen a recombinant ( $r$ ) SapA-N and SapA-C codified proteins. The Elisa results indicated that the immunological activity of rSAP-N was highter that that of rSAP-C, but both proteins appeared as bands of approximately $66,2 \mathrm{kDa}$ on a $12 \%$ polyacrylamide gel.
Evaluating acid extracts of $C$. fetus samples, Dunn et al. (1987) assume that the bands between 50 and $63 \mathrm{kDa}$ represent breakdown products of the flagellar antigen. The electrophoresis profile of $C$. fetus subsp. venerealis and $C$. fetus subsp. fetus samples indicated the presence of one and two bands, respectively, with similar molecular weight (Fig.1). In the immunoblotting, the recognition of this $C$. fetus subsp. venerealis band was weak, possibly indicating protein breakdown. However, a definite band, of 56,7 kDa was recognized in $C$. fetus subsp. fetus. This disparity can only be elucidated by bi-dimensional gel electrophoresis.

The role of the protein migrating at $97 \mathrm{kDa}$, is a SAP antigen (Blaser et al. 1985, Tu et al. 2004), was not evident in the IgA ELISA performed, and was recognized only for C. fetus subsp. venerealis. It may have contributed to test specificity for the detection of animals truly infected by this subspecies, and for the lasting immunity against $C$. fetus subsp. venerealis, allowing the resistance to reinfection. Blaser et al. (1985) and Blaser et al. (1987) showed that this protein migrates up to $100 \mathrm{kDa}$, it is associated to the resistance of $C$. fetus to human antibodies, and it is labile when extracted by acid. It can be spontaneously lost when the bacterium is cultivated in vitro (Winter et al. 1978, Blaser et al. 1987), which may have occurred with the $C$. fetus subsp. fetus sample (Fig.1.).

In sheep, Grogono-Thomas et al.(2000) suggested that the $97 \mathrm{kDa}$ protein of the $\mathrm{S}$ layer is essential for the colonization and passage of $C$. fetus subsp. fetus through the placenta, but that it is not directly responsible for fetal injury. After the abortion, a lasting immunity against $C$. fetus subsp. fetus is produced by systemic antibodies that are specific against the $S$ layer proteins.

The phenomenon of persistent infection of females by C. fetus subsp. venerealis seems to be related to changes in SAP proteins, which migrate around $97 \mathrm{kDa}$, as suggested by several authors (Garcia et al. 1995, GrogonoThomas et al. 2000, Vargas et al. 2002, Tu et al. 2004), and that were strongly recognized in the immunoblotting assay performed. Therefore, these proteins may be an interesting alternative for testing, as they allow the identification of females with persistent $C$. fetus subsp. venerealis infection. In addition, if we also take into account the relevant participation of these proteins in the mechanism that $C$. fetus uses to evade the immune system, these proteins are potential candidates for the production of mucosal vaccines aiming at the control of bovine genital campylobacteriosis.

A vaccine produced from $C$. fetus ssp. fetus which protected against ovine abortion comprised of a bacterial extract containing a "rather loosely attached capsular envelope protein" was later characterized as a surface microcapsule which mediated protection against phagocytosis The antigen was purified and characterized as a protein with an apparent molecular mass of 98000 existing as a complex with lipopolysaccharide (Beveridge et al., 1997).Vaccines to promote immunity against $C$. fetus subsp. venerealis and Tritrichomonas foetus has been 
tested (Cobo et al. 2004) and the author observed an intravaginal instillation of $C$. fetus subso venerealis and $T$. foetus had been so sucessful to imunize the heifers using three different routes intravenous, subcutaneous and into the vaginal submucosa associated with a subcutaneous route. So, it seems that the route of antigen entrance in the organism is important to enhance the serological response, but only determination of systemic IgG, for both organisms were performed and no experiment were performed with intravaginal route only to define what is the most important (Cobo et al. 2004). For the serological test to $C$. fetus subsp. veneralis immune response these authors used a sonicated antigen whose procedure of extraction were similar to the used in this work but eletroforetic profile of extracted proteins were not presented.

The use of immunoblotting in cervico-vaginal mucus samples for the diagnosis of bovine genital campylobacteriosis in herds with no history of the disease could be a promissing tool for the elucidation of false positive results obtained in the ELISA, but it is a laborious and expensive test. An alternative test, could be the dot blot assay has been developed for serodiagnosis of several agents or related species, providing an objective evaluation and a convenient, time-saving, and inexpensive method (CardonaCastro et al. 2000, Pinheiro et al. 2006). The standardized assay using an acid extractable antigen has a great potential for the identification of animals infected by $C$. fetus. It is best indicated for herd diagnosis due to the appearance of false positive results in herds with no history of the disease. Therefore, the diagnosis must be supported by the reproductive history of the herd and by clinical signs indicating the presence of Bovine Genital Campylobacteriosis.

Acknowledgements.- This study received financial support from Embrapa Pantanal, Fundação de Apoio ao Desenvolvimento do Ensino, Ciência e Tecnologia do Estado de Mato Grosso do Sul (Fundect), Fundação de Amparo à Pesquisa do Estado de Minas Gerais (Fapemig), and Fundação de Estudo e Pesquisa em Medicina Veterinária Preventiva (FEP/MVZ) Coordenação Preventiva. A.O. Pellegrin, A.P. Lage, and K.L. Miranda were supported by grants of Conselho Nacional de Desenvolvimento Científico e Tecnológico (CNPq). J.F. Figueiredo was supported by a grant from CAPES.

\section{REFERENCES}

Beveridge T.J. , Pouwels P.H., Sara M., Kotiranta A., Lounatmaa K., Kari K., Kerosuo E., Haapasalo M., Egelseer E.M., Schocher I., Sleytr U.B., Morelli L., Callegari M.-L., Nommelini J.F., Bingle W.H., Smit J., Leibovitz E., Lemaire M., Miras I., Salamitou S., Béguin P., Ohayon H., Gounon P., Matuschek M., Sahm K., Bahl H., GrogonoThomas R., Dworkin J., Blaser M.J., Woodlank R.M., Newel D.G., Kessel M. \& Koval S.F.V. 1997. Functions of S-layers, FEMS. Microbiol. Rev. 20:99-149.

Bjerrum O.J. \& Heegaard N.H.H. 1988. Handbook of Immunoblotting of Proteins. Vol.2. CRC Press, Raton. 214p.

Blaser M.J., Hopkins J.A., Berka R.M., Vasil M.L. \& Wang W.L.L. 1983. Identification and characterization of Campylobacter jejuni outer membrane proteins. Infect. Immun. 42:276-284.

Blaser M.J., Smith P.F., Hopkins J.A., Bryner J., Heinzer I. \& Wang W.L.L. 1987. Pathogenesis of Campylobacter fetus infections. I. Serum resistance associated with high molecular weight surface proteins. J. Infect. Dis. 155:696-706.
Blaser M.J., Smith P.F. \& Kohler P.F. 1985. Susceptibility of Campylobacter isolates to the bactericidal activity in human serum. J. Infect. Dis. 151:227-235.

Blaser M.J. \& Pei Z. 1993. Pathogenesis of Campylobacter fetus infections: Critical role of high-molecular-weight S-layer proteins in virulence. J. Infect. Dis. 167:372-377.

Blaser M.J., Smith P.F., Repine J.E. \& Joiner K.A. 1988. Pathogenesis of Campylobacter fetus infections: Failure of encapsulated Campylobacter fetus to bind $\mathrm{C} 3 \mathrm{~b}$ explains serum and phagocytosis resistance. J. Clin. Invest. 81:1434-1444.

Cardona-Castro N., Gotuzzo E., Rodriguez M. \& Guerra H. 2000. Clinical application of a dot blot test for diagnosis of enteric fever due to Salmonella enterica serovar typhi in patients with typhoid fever from Colombia and Peru. Clin. Diagn. Lab. Immunol. 7:312-313.

Cobo E., Cipolla A., Morsella C., Cano D. \& Campero C. 2003. Effect of two commercial vaccines to Campylobacter fetus subspecies on heifers naturally challenged. J. Vet. Med. B 50:75-80.

Corbeil L.B., Duncan J.R \& Schuring G.G.D. 1974a. Bovine venereal vibriosis: variations in immunoglobulin class of antibodies in genital secretions and serum. Infect. Immun. 10:1084-1090.

Corbeil L.B., Schuring G.G.D. \& Bier P.J. 1975. Bovine venereal vibriosis: Antigenic variation of the bacterium during infection. Infect. Immun. 11:240-244.

Corbeil L.B., Schuring G.G.D. \& Duncan J.R. 1974b. Immunoglobulin classes and biological functions of Campylobacter (Vibrio) fetus antibodies in serum and cervico-vaginal mucus. Infect. Immun. 10:422429.

Dekeyser P.J. 1986. Bovine genital campilobacteriosis, p.263-266. In: Morrow D.A. (Ed.), Current Therapy in Theriogenology. $2^{\text {nd }}$ ed. W.B. Saunders Company, Philadelphia.

Dunn B.E., Blaser M.J. \& Snyder E.L. 1987. Two dimensional gel eletrophoresis and immunoblotting of Campylobacter outer membrane proteins. Infect. Immnun. 55:1564-1572.

Fernandes J.C.T. \& Gomes M.J.P. 1992. Campilobacteriose genital bovina, p.141-150. In: Charles T.P. \& Furlong J. (Eds), Doenças dos Bovinos de Leite Adultos. Embrapa-CNPGL, Coronel Pacheco, MG.

Garcia M.M., Lutze Wallace C.L., Denes A.S., Eaglesome M.D., Holst E. \& Blaser M.J. 1995. Protein shift and antigenic variation in the Slayer of Campylobacter fetus subsp. venerealis during bovine infection accompanied by genomic rearrangement of sapA homologs. J. Bacteriol. 177:1976-1980.

Grogono-Thomas R., Dworkin J., Blaser M.J. \& Newel D.G. 2000. Roles of the surface layer proteins of Campylobacter fetus subsp. fetus in ovine abortion. Infect. Immun. 68:1687-1691.

Hewson P.I. 1985. Enzyme-linked immunosorbent assay for antibodies to Campylobacter fetus in bovine vaginal mucus. Res. Vet. Sci. 38:41-45.

Hirschl A.M. \& Rotter M.L. 1990. Serodiagnosis of Helycobacter pylori infections: Suitability of various antigen preparations, p.141-146. In: Malferthertheiner P. \& Ditschuneit H. (Eds), Helicobacter pylori, Gastritis and Peptic Ulcer. Springer-Verlag, Berlin.

Hum S., Quinn C. \& Kennedy D. 1994. Diagnosis of bovine campylobacteriosis by ELISA. Aust. Vet. J. 71:140-143.

Hum S., Stephens L.R. \& Quinn C. 1991. Diagnosis by ELISA of bovine abortion due to Campylobater fetus. Aust. Vet. J. 68:272-275.

Laemmli U.K. 1970. Cleavage of structural proteins during the assembly of the head of the bacteriophage T4. Nature 227:680-685.

Lewala-Guruge J., Nilsson I., Ljungh Â. \& Wadstrôm T. 1992. Cell surface proteins of Helicobacter pylori as antigens in an Elisa and a comparison with three commercial ELISA. Scand. J. Infect. Dis. 24:451-465.

Logan S.M. \& Trust T.J. 1983. Molecular identification of surface protein antigens of Campylobacter jejuni. Infect. Immun. 42:675-682. 
Logan S.M. \& Trust T.J. 1986. Location of epitopes on Campylobacter jejuni flagella. J. Bacteriol. 168:739-745.

McCoy E.C., Doyle D., Burda K., Corbeil L.B. \& Winter A.J. 1975. Superficial antigens of Campylobacter (Vibrio) fetus: Characterization of an antiphagocytic component. Infect. Immun. 11:517-525.

McFadden A.M., Heuer C., Jackson R., West D.M. \& Parkinson T.J. 2005. Investigation of bovine venereal campylobacteriosis in beef cow herds in New Zealand. N. Z. Vet. J. 53:45-52.

Pei Z. \& Blaser M.J. 1990. Pathogenesis of Campylobacter fetus infections: Role of surface array proteins in virulence in a mouse model. J. Clin.Invest. 85:1036-1043.

Pinheiro R.R., Olortegui C.D.C., Gouveia A.M.G., Araujo S.C. \& Pinheiro A.A. 2006. Desenvolvimento de dot-blot para detecção de anticorpos para o vírus da Artrite Encefalite Caprina em caprinos. Revta Port. Ciênc.Vet. 101:51-56.

Sambrook J. \& Russell D.W. 2001. Molecular cloning. $3^{\text {rd }}$ ed. Cold Spring Harbor Laboratory Press, USA. 2368p.

Sampaio I.B.M. 1998. Estatística Aplicada à Experimentação Animal. Fundação de Ensino e Pesquisa em Medicina Veterinária e Zootecnia, Belo Horizonte. 221p.

Smith R.D. 1994. Veterinary Clinical Epidemiology: A problem oriented approach. CRC Press, Boca Raton. 234p.

Thompson S.A. 2002. Campylobacter surface-layers (S-layers) and immune evasion. Ann. Periodontol. 7:43-53.
Trust T.J. \& Logan S.M. 1984. Outer membrane and surface structure of Campylobacter jejuni, p.133-142. In: Butzler J.P. (Ed.), Campylobacter Infection in Man and Animals. CRC Press, Boca Raton.

Tu Z.-C., Hui J. \& Blaser M.J. 2004. Conservation and diversity of sap homologues and their organization among Campylobacter fetus isolates. Infect. Immun. 72:1715-1724.

Van Aert A., Dekeyser P., Florent A.F. \& Bouters R. 1977. Nature of Campylobacter fetus agglutinins in vaginal mucus from experimental infected heifers. Brit.Vet. J. 133:88-94.

Vargas A.C., Costa M.M., Vainstein M.H., Kreutz L. \& Neves J.P. 2002. Campylobacter fetus subspecies venerealis surface array protein form bovine isolates in Brazil. Current Microbiol. 45:111-114.

Voller A., Bidwell D.E. \& Bartllett A. 1979. The enzyme-linked immunosorbent assay. Dynatech. Europe, Guernsey.

Wilkie B.N., Duncan J.R. \& Winter A.J. 1972. The origin, class and specificity of immunoglobulin in bovine cervico-vaginal mucus: Variation with parenteral immunization and local infection with Vibrio fetus. J. Reprod. Fertil. 31:359-365.

Winter A.J. 1982. Microbial immunity in the reproductive tract. J. Am. Vet. Med. Assoc.173:1069-1073.

Winter A.J., McCoy E.C., Fullmer C.S., Burda K. \& Bier P.J. 1978. Microcapsule of Campylobacter fetus: Chemical and physical characterization. Infect. Immun. 22:963-971. 